University of Nebraska - Lincoln

DigitalCommons@University of Nebraska - Lincoln

Is Preventative, Concurrent Management of the Soybean Aphid (Hemiptera: Aphididae) and Bean Leaf Beetle (Coleoptera: Chrysomelidae) Possible?

\author{
Kevin D. Johnson \\ lowa State University \\ Matthew E. O'Neal \\ oneal@iastate.edu \\ Jeffrey Bradshaw \\ University of Nebraska-Lincoln, jbradshaw2@unl.edu \\ Marlin E. Rice
}

Follow this and additional works at: https://digitalcommons.unl.edu/panhandleresext

Part of the Agriculture Commons

Johnson, Kevin D.; O'Neal, Matthew E.; Bradshaw, Jeffrey; and Rice, Marlin E., "Is Preventative, Concurrent Management of the Soybean Aphid (Hemiptera: Aphididae) and Bean Leaf Beetle (Coleoptera: Chrysomelidae) Possible?" (2008). Panhandle Research and Extension Center. 41.

https://digitalcommons.unl.edu/panhandleresext/41

This Article is brought to you for free and open access by the Agricultural Research Division of IANR at DigitalCommons@University of Nebraska - Lincoln. It has been accepted for inclusion in Panhandle Research and Extension Center by an authorized administrator of DigitalCommons@University of Nebraska - Lincoln. 


\title{
Is Preventative, Concurrent Management of the Soybean Aphid (Hemiptera: Aphididae) and Bean Leaf Beetle (Coleoptera: Chrysomelidae) Possible?
}

\author{
KEVIN D. JOHNSON, MATTHEW E. O’NEAL, ${ }^{1}$ JEFFREY D. BRADSHAW, AND MARLIN E. RICE \\ Department of Entomology, Iowa State University, 113A Insectary, Ames, IA 50011
}

\section{J. Econ. Entomol. 101(3): 801-809 (2008)}

\begin{abstract}
In Iowa, the management of insect pests in soybean, Glycine max (L.) Merr., has been complicated by the arrival of the invasive species soybean aphid, Aphis glycines Matsumura (Hemiptera: Aphididae), and occasional outbreaks of bean leaf beetle, Cerotoma trifurcata (Förster) (Coleoptera: Chrysomelidae), populations leading to economic losses. Several insecticide programs designed to reduce abundance of the overwintered and first generation C. trifurcata and the incidence of bean pod mottle virus were evaluated over $3 \mathrm{yr}$ (2004-2006) for their impacts on A. glycines populations, at three locations in Iowa (Floyd, Lucas, and Story counties). There was no significant overlap of either overwintered (early May) or the first (early July) generations of C. trifurcata with A. glycines, because aphids were first detected in June and they did not reach economically damaging levels until August, if at all. During this study, insecticides targeting the overwintered population or the first generation of C. trifurcata provided a limited impact on A. glycines populations compared with untreated controls, and they did not prevent economic populations from occurring. Furthermore, the highest populations of $A$. glycines were frequently observed when a low rate of lambda-cyhalothrin (178 $\mathrm{ml} / \mathrm{ha}$ ) was applied targeting the overwintered population of C. trifurcata. Soybean yields were not protected by any of the insecticide treatments. Our results indicate that the use of either early season foliar or seed-applied insecticides for C. trifurcata management is of limited value for A. glycines management.
\end{abstract}

KEY WORDS Bean pod mottle virus, Aphis glycines, Cerotoma trifurcata, Glycine max

Soybean, Glycine max (L.) Merr., grown in the North Central region of the United States, has historically required few insecticide inputs for arthropod pest management (Fernandez-Cornejo and Jans 1999). Recently, insect pests have threatened soybean production in Iowa during the late 1990s with bean leaf beetle, Cerotoma trifurcata (Förster) (Coleoptera: Chrysomelidae), populations reaching economic levels (Lam and Pedigo 2000; Lam et al. 2001; Krell et al. 2004, 2005) and the arrival of the invasive soybean aphid, Aphis glycines Matsumura (Hemiptera: Aphididae), in 2000 (Ragsdale et al. 2004). Both C. trifurcata and A. glycines cause yield losses from plant feeding (Smelser and Pedigo 1992, Myers et al. 2005a). Additionally, A. glycines and $C$. trifurcata can reduce yield and seed quality by transmitting several plant viruses (Clark and Perry 2002; Krell 2002; Krell et al. 2003a, 2004; Burrows et al. 2005; Davis et al. 2005).

A. glycines is native to Asia, and it was discovered in Wisconsin in July 2000 (Ragsdale et al. 2004). Since its discovery in North America, the range of A. glycines has extended to include at least 20 midwestern states and three Canadian provinces, and as evidenced by its

\footnotetext{
${ }^{1}$ Corresponding author, e-mail: oneal@iastate.edu.
}

range in southeast Asia, it may eventually extend its North American range into the south-central United States (Ragsdale et al. 2004, Venette and Ragsdale 2004). By 2002, A. glycines had been found in every county in Iowa (Rice et al. 2005). In Iowa, A. glycines colonize soybean fields beginning in June, and they have become economically important in July and August (Johnson 2006). A. glycines is an inconsistent pest of soybean in Iowa, with great temporal and spatial variability in the occurrence of economic outbreaks (Johnson 2006). Despite the remarkable fecundity of A. glycines (McCornack et al. 2004), a community of generalist predators within soybean can delay establishment and suppress A. glycines population growth (Fox et al. 2004, 2005; Costamagna and Landis 2006; Schmidt et al. 2007). Given this variability and the impact of predators, growers are recommended to scout soybean fields beginning in July and apply an insecticide when populations exceed 250 A. glycines per plant (Ragsdale et al. 2007).

C. trifurcata is native to North America, and its biology has been well described in Iowa (Smelser and Pedigo 1991, Zeiss et al. 1996, Lam et al. 2001, Krell et al. 2003b, Bradshaw 2007). C. trifurcata overwinter $\left(\mathrm{F}_{0}\right)$ as adults, and it has two generations, with adult 
Table 1. Insecticide, application rates and $C$. trifurcata populations targeted for treatment

\begin{tabular}{lll}
\hline \multicolumn{1}{c}{ Insecticide ${ }^{a}$} & \multicolumn{1}{c}{ Rate } & \multicolumn{1}{c}{$\begin{array}{c}\text { Target } \\
\text { pop }^{b}\end{array}$} \\
\hline $\begin{array}{l}\text { Untreated (control) } \\
\text { Thiamethoxam }\end{array}$ & $\begin{array}{l}\mathrm{N}^{c} \mathrm{~A}^{c} \\
\text { Nh/A }\end{array}$ & $\begin{array}{l}\mathrm{N} / 100 \mathrm{~kg} \\
\mathrm{~F}_{0}\end{array}$ \\
$\begin{array}{l}\text { lambda-Cyhalothrin } \\
\text { Lambda-Cyhalothrin }\end{array}$ & $50 \mathrm{~g} / 100 \mathrm{~kg}+227 \mathrm{ml} / \mathrm{ha}$ & $\mathrm{F}_{0}$ and $\mathrm{F}_{1}$ \\
$\begin{array}{l}\text { Lambda-Cyhalothrin } \\
\text { Lambda-Cyhalothrin }+ \\
\text { lambda-Cyhalothrin }\end{array}$ & $227 \mathrm{ml} / \mathrm{ha}$ & $\mathrm{F}_{0}$ \\
\hline
\end{tabular}

${ }^{a}$ Seed treatment rates are given as grams of formulated product per $100 \mathrm{~kg}$ of seed. Foliar treatment rates are given as milliliters of formulated product per hectare. Foliar insecticide was lambda-cyhalothrin (Warrior 1SC, Syngenta Crop Protection) and the seed treatment insecticide was thiamethoxam (Cruiser 5 FS, Syngenta Crop Protection).

${ }^{b}$ Populations denoted as overwintered $\left(\mathrm{F}_{0}\right)$ and first $\left(\mathrm{F}_{1}\right)$ generation of C. trifurcata

${ }^{c}$ Not applicable.

peak abundance for first $\left(F_{1}\right)$ and second $\left(F_{2}\right)$ generations in mid-July and late August, respectively. Adult C. trifurcata cause economic injury as leaf defoliators and pod feeders (Pedigo and Zeiss 1996, Lam and Pedigo 2001). In Iowa, targeting the overwintered and first generation of $C$. trifurcata with either a seed treatment (neonicotinoid) or a foliar insecticide (typically a pyrethroid or organophosphate) can reduce $C$. trifurcata populations and the incidence of bean pod mottle virus (family Comoviridae, genus Comovirus, BPMV) (Krell et al. 2004) in soybean. Both neonicotinoid and pyrethroid insecticides are active against C. trifurcata and A. glycines (Ragsdale et al. 2004); therefore, it is possible that both pests could be managed within the same program. However, it is not clear whether a seed treatment applied at planting or a foliar insecticide applied in early June to early July would be effective for suppressing or delaying A. glycines outbreaks given its' phenology in Iowa. According to McCornack and Ragsdale (2006), neonicotinoid insecticides applied as seed treatments reduced A. glycines population growth rates in Minnesota. However, this reduction in population growth rate did not result in higher soybean yield.

Our objective was to determine whether the management of $C$. trifurcata for the reduction of BPMV would affect the impact of A. glycines on soybean yield in Iowa. We hypothesize that seed- or foliar-applied insecticides used alone or in combination for the control of C. trifurcata would reduce A. glycines populations and that they would provide greater population reduction and soybean yield protection compared with untreated plots.

\section{Materials and Methods}

Experimental Design. The experiment was conducted over 3 yr (2004-2006), and at three locations (Floyd, Lucas, and Story counties) in Iowa. Treatments consisted of seed-applied (thiamethoxam; Cruiser, Syngenta Crop Protection, Greensboro, NC)
Table 2. Timing of insecticides to suppress overwintered $\left(F_{0}\right)$ and first $\left(F_{1}\right)$ generation $C$. trifucata

\begin{tabular}{clllc}
\hline \hline \multirow{2}{*}{ Yr } & County & Planting date & \multicolumn{2}{c}{$\begin{array}{c}\text { Foliar insecticide } \\
\text { application date }\end{array}$} \\
\cline { 4 - 5 } & & & $\mathrm{F}_{0}$ & $\mathrm{~F}_{1}$ \\
\hline 2004 & Floyd & 3 May & 19 May & 8 July \\
& Story & 28 April & 20 May & 4 July \\
& Floyd & 22 May & 1 June & 22 June \\
& Story & 23 May & 7 June & 21 June \\
& Lucas & 5 May & 2 June & 23 June \\
& Floyd & 6 May & 5 June & 13 July \\
& Story & 28 April & 8 June & 10 July \\
\hline
\end{tabular}

or foliar-applied (lambda-cyhalothrin; Warrior, Syngenta Crop Protection, Greensboro, NC), insecticides used alone or in combination (Table 1). Insecticide applications were timed to either prevent feeding by the $\mathrm{F}_{0}$ population of $C$. trifurcata, the $\mathrm{F}_{1}$ generation of C. trifurcata, or both the $\mathrm{F}_{0}$ and $\mathrm{F}_{1}$ generations of $C$. trifurcata. In total, five different insecticide treatments and an untreated control were tested. The general-use rate (CDMS 2007) of lambda-cyhalothrin for management of C. trifurcata in soybean ranges from 134 to 227 $\mathrm{ml} /$ ha (from 1.8 to $3.2 \mathrm{fl} \mathrm{oz} /$ acre). The $\mathrm{F}_{0}$ population of $C$. trifurcata was targeted with a rate of $178 \mathrm{ml} / \mathrm{ha}$ and when lambda-cyhalothrin was applied to manage the $F_{1}$ generation of $C$. trifurcat $a$ the maximum rate of $227 \mathrm{ml} /$ ha was chosen to maximize the residual activity. In all years, applications were based on the detection of $F_{0}$ C. trifurcata on emerging soybeans or teneral C. trifurcata (signaling the emergence of the $\mathrm{F}_{1}$ generation). C. trifurcata populations were monitored weekly by using two different methods of sampling. In situ counts of C. trifurcata on $5 \mathrm{~m}$ of row were used when soybean plants were in early vegetative stages (VE-V4), and foliar sampling consisted of 20 pendulum sweeps with a 38 -cm-diameter sweep net running the direction of the row when plants were in later vegetative and reproductive stages $(\geq \mathrm{V} 4)$ (Bradshaw 2007). Variation in the timing of foliar insecticide occurred due to differences in the detection date of teneral C. trifurcata across locations and years (Table 2).

In 2004, at all locations, soybean (variety Mark 0124 $\mathrm{RR}$, glyphosate tolerant) were planted in six $76-\mathrm{cm}$ rows, and treatments were applied to plots measuring 10 by $34 \mathrm{~m}$ at a population of 456,000 seeds per ha $(190,000$ seeds per acre). Plots were arranged in a randomized complete block design with eight replicates. Foliar insecticides were applied using a groundpulled sprayer applying 142 liters/ha (15 gpa) at 137 kpa (20 psi) at all locations. All aphid counts were taken from the center four rows to control for edge effects. Additionally, yields were also only taken from the center four rows with the exception of the Floyd County location. At this location a border row was harvested to accommodate limitations of the available equipment. From 2004 to 2006, several experimental parameters were changed: plot size, number of replicates, and application technique for foliar insecticides and treatments. The 2004 experiment was part of 
a larger study investigating the affects of various insecticides on C. trifurcata populations and BPMV incidence (Bradshaw 2007). In 2005 and 2006, the study was focused to determine treatment effects on $A$. glycines populations. Because of the reduced trivial movement of A. glycines compared with $C$. trifurcate, plot size was reduced (Wang and Ghabrial 2002). Therefore, in 2005 the same experimental design was used as in 2004 except for the following changes: soybean variety NK S24-K4 (glyphosate tolerant) was used at all three locations, treatments were replicated six times, plot size was 5 by $34 \mathrm{~m}$, and foliar insecticides were applied using a backpack sprayer applying 237 liters/ha (20 gpa) at $274 \mathrm{kpa}$ (40 psi). In 2005, the application rate for all treatments with lambda-cyhalothrin was increased from $178 \mathrm{ml} /$ ha to $227 \mathrm{ml} / \mathrm{ha}$. In 2006, all parameters were as in 2005 except for soybean variety (NK S23-Z3, glyphosate tolerant) and plot dimensions ( 10 by $15 \mathrm{~m}$ ) were adjusted to accommodate field sites.

In 2004 experiments were conducted at two Iowa State University research farms-Northeast Research Farm in Floyd County and Curtiss Research Farm in Story County. In 2005, we anticipated an increase in soybean aphid outbreaks (Rice et al. 2005), so an additional site (McNay Research Farm, Lucas County) was added. In 2006, the experiment was repeated at the Floyd and Story County research farms. The Lucas County site was removed in 2006 due to a consistent trend of subeconomic populations (below both the economic threshold and economic injury level (EIL); Ragsdale et al. 2007) of A. glycines. The counties are referred to from north to south with Floyd County in northeastern Iowa, followed by Story County in central Iowa, and Lucas County in south-central Iowa.

Estimation of A. glycines Populations. Populations of A. glycines (apterae, alatae, and nymphs) were counted weekly (last week of May through the second week of September) on consecutive plants within each plot. In 2004, 10 consecutive plants were randomly selected from the center four rows within each plot, and A. glycines were counted on those plants. In 2005 and 2006, the number of consecutive plants ranged from five to 20 , with the number of plants counted determined by the proportion infested with aphids during the previous sampling date (Hodgson et al. 2004). When 0 to $80 \%$ of plants were infested with A. glycines, A. glycines on 20 plants were counted; when 81 to $99 \%$ of plants were infested, A. glycines on 10 plants were counted; at $100 \%$ infestation, A. glycines on five plants were counted, and plants were randomly selected from the center eight rows within each plot.

The seasonal exposure of soybean to A. glycines was reported in units of "cumulative aphid days (CAD)," calculated based on the number of aphids per plant between two sampling dates:

$$
\sum_{n=1}^{\infty}=\left(\frac{x_{i-1}+x_{i}}{2}\right) \times t
$$

Table 3. Impact of all significant fixed and random effects on A. glycines populations from 2004, 2005, and 2006 combined

\begin{tabular}{llrr}
\hline \multicolumn{1}{c}{ Source } & \multicolumn{1}{c}{ df } & $F$ value & $P$ value \\
\hline Treatment & 5,2049 & 2.3 & 0.0422 \\
Yr & 2,2049 & 258.5 & $<0.0001$ \\
$W k$ & 10,2049 & 573.5 & $<0.0001$ \\
Location $^{a}$ & 1,14 & 42.5 & $<0.0001$ \\
Location $\times$ yr & 2,2049 & 60.3 & $<0.0001$ \\
Treatment $\times$ location & 5,2049 & 2.8 & 0.0153 \\
\hline
\end{tabular}

${ }^{a}$ One-way ANOVA (Lucas County removed) and with year treated as a random effect.

where $x$ is the mean number of aphids on sample day $i, x_{\mathrm{i}-1}$ is the mean number of aphids on the previous sample day, and $t$ is the number of days between samples $i-1$ and $i$. Summing aphid days accumulated during the growing season or CAD provides a measure of the seasonal aphid exposure that a soybean plant experienced (Hodgson et al. 2004).

Yield. Yields were determined in 2005 and 2006 by weighing grain with a grain hopper, which rested on a digital scale sensor custom designed for each of the three harvesters. Yields were corrected to $13 \%$ moisture, and they are reported as kilograms per hectare. Yield data from 2004 are part of an additional experiment and are already reported by Bradshaw (2007).

Data Analysis. Average aphid days accumulated each week were calculated for each treatment throughout the growing season. The affect of insecticide treatments on accumulation of aphid days was determined using natural log-transformed data to meet the assumptions of analysis of variance (ANOVA). To test the affect of insecticide treatments for C. trifurcata control on the establishment and population growth of A. glycines, a repeated measures ANOVA was used. The repeated statement consisted of an interaction among the following factors: year, week, location, treatment and block with blocks nested within locations. Both year and block (location) were considered random factors. A repeated measures ANOVA was performed with a Toeplitz covariance structure, which provided the best model fit in PROC MIXED (SAS Institute 2004). To analyze the year-to-year variability, data were pooled across years and locations with the exception of data from the Lucas County due to the lack of data spanning multiple years. In addition to an analysis of pooled data, individual locations within a year were analyzed using a one-way ANOVA in PROC MIXED (SAS Institute 2004) and F-protected least-squares means for mean separation. These same analyses were used to determine the effect of experimental treatments on soybean yield. The population growth rates of A. glycines were analyzed using a one-way ANOVA in PROC MIXED and F-protected least-squares means test for mean separation. Population growth rates were analyzed using PROC MIXED and F-protected leastsquares means test for mean separation were used to determine whether population growth rates differed among any of the treatments. 
Table 4. Mean peak abundance of $A$. glycines per plant in the control treatment for each location in 2004, 2005, and 2006

\begin{tabular}{cccc}
\hline \hline \multirow{2}{*}{ Yr } & \multicolumn{3}{c}{ Peak abundance $^{a}$ (mean \pm SEM) } \\
\cline { 2 - 4 } & Floyd & Story & Lucas \\
\hline 2004 & $13 \pm 3$ & $46 \pm 18$ & NA \\
2005 & $507 \pm 81$ & $281 \pm 82$ & $87 \pm 14$ \\
2006 & $141 \pm 63$ & $15 \pm 11$ & NA \\
\hline
\end{tabular}

${ }^{a}$ In 2004, peak abundance occurred on 17 and 25 August for Floyd and Story counties, respectively. In 2005, peak abundance occurred on 25, 29, and 18 August for Floyd, Story, and Lucas counties, respectively. In 2006, peak abundance occurred on 31 July and 9 August for Floyd and Story counties, respectively.

\section{Results}

There was a large amount of variation in A. glycines populations by year and location (Table 3 ). During 2004 and 2006, A. glycines populations did not reach the economic threshold ( 250 aphids per plant; Ragsdale et al. 2007) at any of the study sites (Table 4). In 2005 , populations at two locations surpassed both the economic threshold and the EIL. Given this variation we summarized the treatment effects by year (Fig. 1; Table 5).

In 2004, there were no economically damaging populations of $A$. glycines at any of our study sites. A. glycines were first detected on 22 July in Floyd County and 23 June in Story County. Populations peaked at different densities in the control treatment at both locations (Table 4). Despite these low populations, significant differences in A. glycines abundance due to treatment and location effects were observed (Table $5)$. The only insecticide treatment that resulted in $A$. glycines exposure significantly lower than untreated plots were those in which seeds and foliage were treated with insecticide or two applications of a foliar insecticide were made (Fig. $2 \mathrm{a}$ and b). In summary, these preventative insecticide treatments did not re-
Table 5. Impact of treatments on cumulative $A$. glycines presence on soybean

\begin{tabular}{llrr}
\hline \hline \multicolumn{1}{c}{ Source $^{a}$} & \multicolumn{1}{c}{$\mathrm{df}$} & $F$ value & $P$ value \\
\hline 2004 & & & \\
Treatment & 5,828 & 3.12 & 0.0084 \\
Wk & 10,828 & 539.14 & $<0.0001$ \\
$\quad$ Location & 1,14 & 362.29 & $<0.0001$ \\
$\quad$ Treatment $\times$ location & 5,828 & 0.78 & 0.5600 \\
2005 & 5,884 & 7.48 & $<0.0001$ \\
$\quad$ Treatment & 10,884 & 571.78 & $<0.0001$ \\
Wk & 2,15 & 274.53 & $<0.0001$ \\
Location & 10,884 & 1.61 & 0.1000 \\
Treatment $\times$ location & & & \\
2006 & 5,720 & 3.92 & 0.0483 \\
$\quad$ Treatment & 10,720 & 639.14 & $<0.0001$ \\
Wk & 1,10 & 372.29 & $<0.0001$ \\
Location & 5,720 & 0.78 & 0.4600 \\
Treatment $\times$ location & & & \\
\hline
\end{tabular}

${ }^{a}$ ANOVA was conducted by pooling data across locations by year.

duce aphid population growth rates as compared with untreated plots at all three locations (Table 6).

In 2005, economically damaging A. glycines populations occurred at two of the three locations (Floyd and Story counties; Table 4). A. glycines were first detected on 27 June (Floyd County), 22 June (Story County), and 1 June (Lucas County). By August, A. glycines populations peaked in the control treatment at all three locations, and they were above the economic threshold at two locations (Floyd and Story counties; Table 4). Significant differences in soybean exposure to A. glycines were detected across the insecticide treatments (Table 5). Despite exceeding the economic threshold, there was no observable effect on soybean yield by any of the insecticide treatments at the Story County site (Fig. 3b). Although significant differences in soybean exposure to A. glycines were observed in 2005 (Table 5), no insecticide treatment prevented A. glycines populations from exceeding the

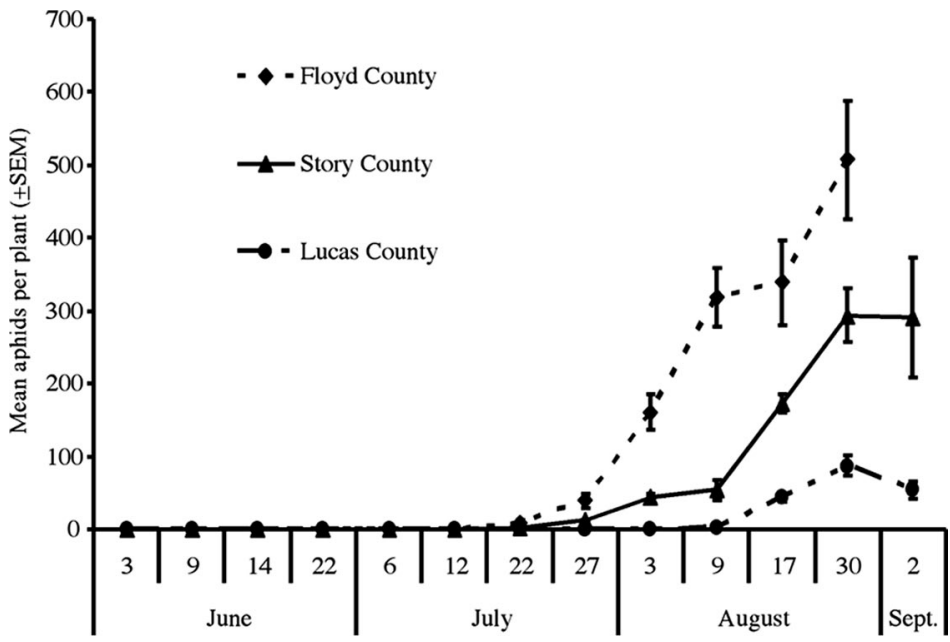

Fig. 1. Mean seasonal abundance of A. glycines in the untreated control plots in 2005 by location. Means were calculated by averaging across replications. All three locations (Floyd, Story, and Lucas counties) were significantly different from each other $(P<0.05)$ 


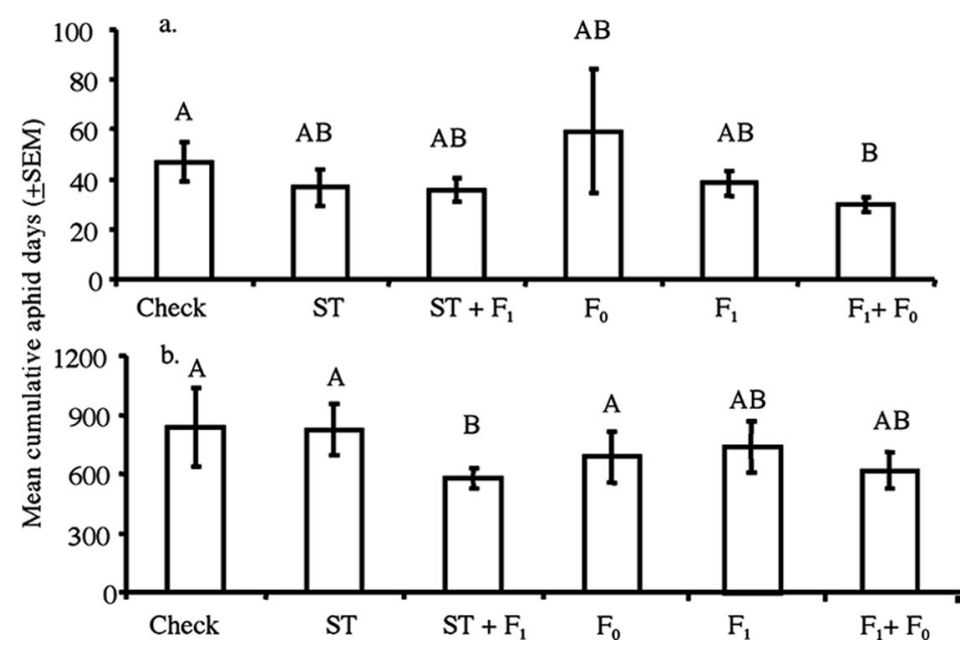

Fig. 2. Impact of insecticides on A. glycines as applied for suppression of C. trifurcata to manage BPMV in soybean. Exposure of soybean to A. glycines based on average cumulative aphid days at (a) Floyd County and (b) Story County in 2004. Thiamethoxam (Cruiser 5 FS, Syngenta Crop Protection) was seed applied, and lambda-cyhalothrin (Warrior 1 SC, Syngenta Crop Protection) was applied to foliage based on the emergence of the overwintered $\left(\mathrm{F}_{0}\right)$ or first $\left(\mathrm{F}_{1}\right)$ generation of C. trifurcata. Timing of insecticide applications varied across locations due to phenology of C. trifurcata. Plots were planted on 3 May at Floyd County and on 28 April at Story County. ST, seed treatment. Means labeled with a unique letter were significantly different $(P<0.05)$.

economic threshold at the same time as those plots that were left untreated. In 2005, preventative insecticide treatments did not provide yield protection or reduce aphid population growth rates as compared with untreated plots at all three locations (Table 6).

In 2006, economically damaging populations of $A$. glycines were not experienced at any location and populations were below the economic threshold. A. glycines first were detected on 6 July in Floyd County and 31 May in Story County. Populations peaked at different densities in the control treatment across both locations (Table 4). Despite these low populations, significant differences in A. glycines exposure levels due to treatment and location effects were observed (Table 5). In 2006, the only treatment that experienced lower A. glycines exposure than the control was the thiamethoxam-treated seed that also received lambda-cyhalothrin at the emergence of the $\mathrm{F}_{1}$ generation of C. trifurcata in Story County (Fig. $4 \mathrm{a}$ and b). In 2006, preventative insecticide treatments also did not provide yield protection or reduce population growth rates compared with untreated plots at all three locations.

Table 6. Impact of treatments on A. glycines pop growth rates on soybean

\begin{tabular}{lcrc}
\hline \hline Source $^{a}$ & df & F value & $P$ value \\
\hline Treatment & 6,258 & 0.51 & 0.68 \\
Yr & 2,258 & 5.52 & 0.005 \\
Location & 2,258 & 21.77 & $<0.0001$ \\
\hline
\end{tabular}

${ }^{a}$ Nonsignificant two-way interactions were removed.

\section{Discussion}

A preventative insecticide program (one that applies an insecticide without reference to pest populations) is only appropriate against a severe pest whose population equilibrium position is consistently above an EIL (Stern et al. 1959). Additionally, a preventative treatment should not result in pest resurgence later in the growing season or increase the likelihood of resistance development (Stern et al. 1959). As observed in this study, the preventative tactics examined are not appropriate for A. glycines management. Although the use of seed treatments and foliar insecticides applied before A. glycines arrive could be justified based on the risk of C. trifurcata (Krell 2002, Krell et al. 2004), the use of these products in absence of the need for $C$. trifurcata management is not effective for A. glycines management. Factors leading to this conclusion include the year-to-year variation in A. glycines populations and the occurrence of economic populations in Iowa past the period in which insecticides used in this study would still be active (McCornack and Ragsdale 2006).

There was significant variability in A. glycines populations, with nearly a ten-fold difference in the peak aphid populations across the three years that this study was conducted. A. glycines populations were below the economic threshold of 250 aphids per plant in both 2004 and 2006 at all locations. This variation is not limited to Iowa (Myers et al. 2005a,b), and since its introduction into the United States, the risk of $A$. glycines outbreaks seems to vary greatly from year to year (Myers et al. 2005b), and from location to location within a given year (Myers et al. 2005a). Since its arrival in Iowa, A. glycines populations have reached 

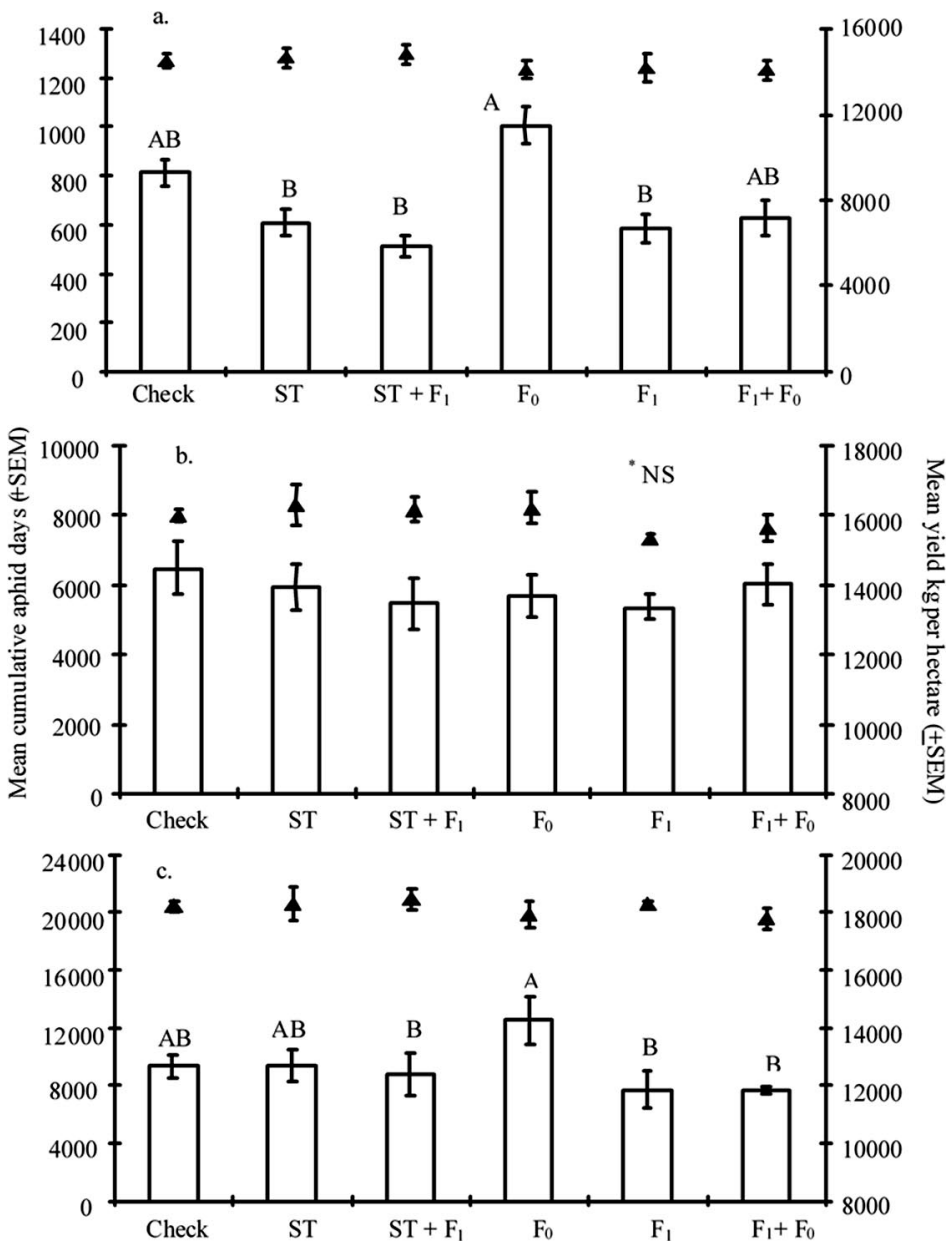

Fig. 3. Impact of insecticide treatments on soybean exposure to A. glycines (average cumulative aphid days; bars, left axis) and yield (average kilograms per hectare; triangles, right axis) at Floyd County (a), Story County (b), and Lucas County (c) in 2005. Thiamethoxam (Cruiser 5 FS, Syngenta Crop Protection) was applied to seed, and lambda-cyhalothrin (Warrior $1 \mathrm{SC}$, Syngenta Crop Protection) was applied based on the emergence of the overwintered $\left(\mathrm{F}_{0}\right)$ or first $\left(\mathrm{F}_{1}\right)$ generation of C. trifurcata. Timing of insecticide applications varied across locations due to phenology of C. trifurcata. Plots were planted on 22 May at Floyd County, on 23 May at Story County, and on 5 May at Lucas County. ST, seed treatment. Means labeled with a unique letter were significantly different $(P<0.05)$. Yields were not significantly impacted significantly for Floyd, Story, or Lucas counties $(P>0.05)$.

economic levels in three of the past 7 yr (M.E.O., unpublished data). Based on temporal and spatial variation of A. glycines preventative insecticide treatments are ineffective to economically manage A. glycines populations.

We did not observe an overlap in the occurrence of A. glycines during the growing season with the overwintered generation and first generation of $C$. trifurcata. The overwintered generation of C. trifurcata feed on soybean plants as soon as they emerge. The emergence of the $\mathrm{F}_{1}$ generation of C. trifurcata typically occurs near the first week of July in Iowa (Smelser and Pedigo 1991). Other researchers have documented population reductions of $A$. glycines due to seed treated with thiamethoxam; however, A. glycines mortality was not observed $35 \mathrm{~d}$ after planting (McCornack and Ragsdale 2006). Although we observed A. glycines as early as the first week of June (Fig. 1) in the untreated plots, populations of A. glycines did not reach economically significant levels until late July or early August, nearly $60 \mathrm{~d}$ after planting. By this time, we expect limited, if any, residual activity from thiamethoxam as a seed treatment (McCornack and Ragsdale 2006).

In general, insecticides applied targeting C. trifurcata had little measurable effect on soybean exposure to A. glycines (Fig. 3), and no insecticide treatment had any detectable effect on soybean yield (Fig. 3). A lack of detectable effect on yield may be because $A$. glycines and C. trifurcata populations were below a detectable injury level. This is likely the case in 2004 and 2006 when populations in untreated plots at all locations were below the economic threshold. A possible explanation for the lack of yield differences in 


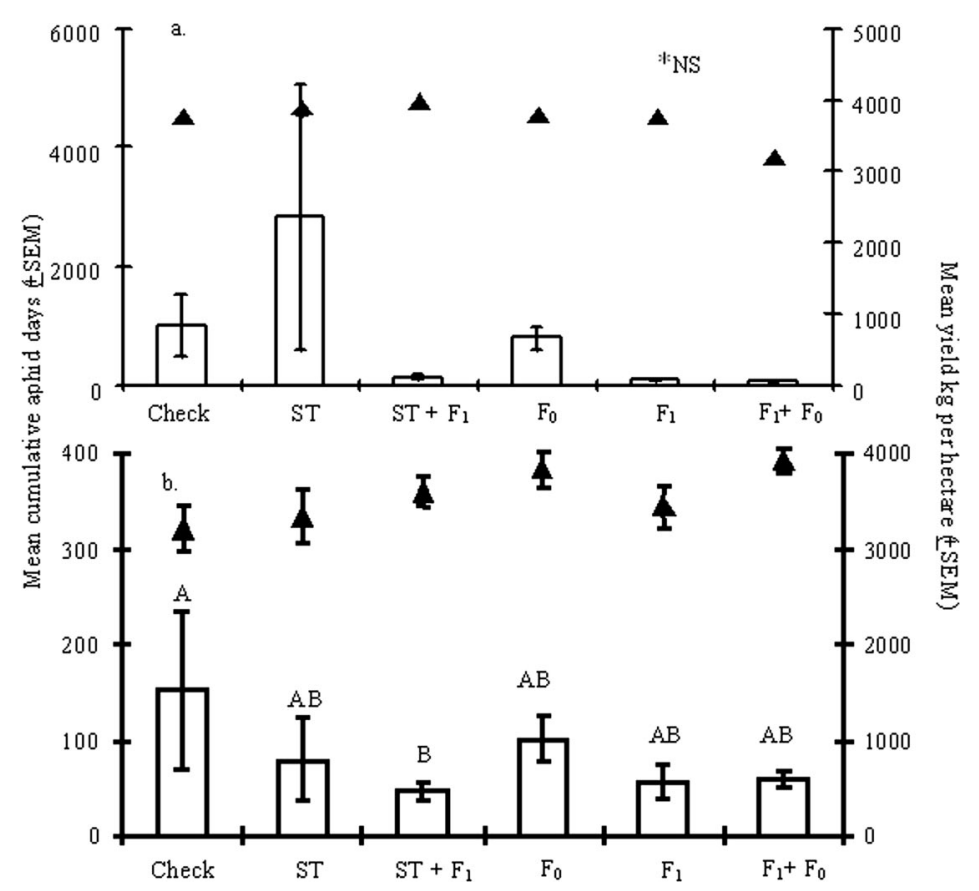

Fig. 4. Impact of insecticide treatments on soybean exposure to A. glycines (average cumulative aphid days; bars, left axis) and yield (average kilograms per hectare; triangles, right axis) at Floyd County (a) and Story County (b) in 2006. Thiamethoxam (Cruiser 5 FS, Syngenta Crop Protection) was applied to seed, and lambda-cyhalothrin (Warrior 1 SC, Syngenta Crop Protection) was applied based on the emergence of the overwintered $\left(\mathrm{F}_{0}\right)$ and first $\left(\mathrm{F}_{1}\right)$ generation of $C$. trifurcata. Timing of insecticide applications varied across locations due to phenology of C. trifurcata. Plots were planted on 6 May at Floyd County and on 28 April at Story County. ST, seed treatment. Means labeled with a unique letter were significantly different $(P<0.05)$. Yields were not significantly impacted significantly for Floyd, Story, or Lucas counties $(P<$ $0.05)$.

2005 in Floyd and Story counties is that none of the treatments prevented the A. glycines population from reaching the EIL. In related studies conducted at the Floyd County research site, we observed significant (16\%) yield improvement when lambda-cyhalothrin was applied based on the 250 per plant threshold (Johnson 2006, Ragsdale et al. 2007). So, even under conditions where a preventative treatment may be justified (i.e., an outbreak year for A. glycines), none of the tactics that we tested provided any measurable yield protection (Fig. 3). We conclude that growers in Iowa that rely on the management of the $\mathrm{F}_{0}$ or $\mathrm{F}_{1}$ generation of $C$. trifurcata with either a seed- or foliarapplied insecticide will see little, if any, benefit toward A. glycines management.

McCornack and Ragsdale (2006) documented a reduction in $A$. glycines population growth by using thiamethoxam seed treatment at a rate of $50 \mathrm{~g} / 100 \mathrm{~kg}$ seed. But, we found no such evidence in Iowa at that same rate. In fact, we found no reduction in A. glycines population growth rates in any of our treatments. This is likely due to a difference in A. glycines phenology between the Minnesota study and our study, with damaging A. glycines populations occurring later in Iowa. The Minnesota study artificially infested soybean plants at the V2 growth stage, whereas the natural occurrence of economic populations were not experienced in Iowa until early August when plants were in reproductive (R) growth stages (Fig. 1).

Preventative treatments should carry a minimal risk of causing ecological backlash if they are to be effective (Pedigo and Rice 2006). Common forms of ecological backlash are the development of insecticide resistance and pest resurgence. Estimating the potential development of insecticide resistance was not a goal of this research. It is not clear what the likelihood of resistance to one or multiple insecticides is for a management program based on preventing disease transmission (Krell et al. 2003a). Pest resurgence can be caused by insecticide applications, which disproportionately affect the beneficial insect community aiding in the establishment of a pest population. At two locations in 2005 (Floyd and Lucas counties), the highest A. glycines exposure levels were observed when a foliar insecticide targeted the overwintered population of $C$. trifurcata, and it was not followed by a second insecticide treatment (Fig. 3a and c). Although these were not statistically higher than the control, they were numerically higher than all other treatments at those locations. A possible explanation is that the earliest application of the foliar pyrethroid may have removed preexisting insect predators resulting in greater A. glycines population growth. Fox et al. $(2004,2005)$ and Schmidt et al. (2007) have shown 
that generalist predators that are present in soybean before the arrival of A. glycines are capable of suppressing aphid establishment and population growth. An example of such a predator is the insidious flower bug, Orius insidiosus (Say). This predator has the potential to slow both establishment and population growth of A. glycines (Rutledge and O'Neil 2005). In Iowa, $O$. insidiosus populations establish in soybean before A. glycines is detected, and they are present from mid-June to mid-September (Bechinski and Pedigo 1981, Schmidt 2006). Although our data suggest that resurgence of A. gylcines can occur, it is not clear how likely this form of ecological backlash will occur.

Management of both C. trifurcata populations (overwintered and first generation) and A. glycines in Iowa is not currently possible with a single or multiple early season insecticide treatments. Timing of insecticides with A. glycines seasonal phenology is important for efficient management of this pest. Based on the temporal and spatial variation of A. glycines populations, preventive insecticides should not be used in Iowa for A. glycines management. The potential of ecological backlash in this system needs more research; resurgence may occur, in some situations, with the preventative use of insecticides. In conclusion, our research provides new information about the management of A. glycines and C. trifurcata in Iowa and provides support for current management recommendations to monitor A. glycines populations through a scouting program by using an economic threshold.

\section{Acknowledgments}

We thank the Iowa State University farm managers Kenneth Pecinovsky, Nicholas Piekema, Dave Starrett, and respective staffs for assistance with management of the soybean plots. We thank the statistics consulting laboratory at Iowa State University for help with data analysis. This study was supported by Hatch Act and State of Iowa funds. In addition to the state of Iowa, we thank the Iowa Soybean Association and North Central Soybean Research Program for financial support of our research and Syngenta Crop Protection for supplying insecticides. This is journal paper 5032 of the Iowa Agriculture and Home Economics Experiment Station, Ames, IA.

\section{References Cited}

Bechinski, E. J., and L. P. Pedigo. 1981. Ecology of predaceous arthropods in Iowa soybean agroecosystems. Environ. Entomol. 10: 771-778.

Bradshaw, J. D. 2007. Bean pod mottle virus biology and management in Iowa. Ph.D. dissertation, Iowa State University, Ames, IA.

Burrows, M.E.L., C. M. Boerboom, J. M. Gaska, and C. R. Grau. 2005. The relationship between Aphis glycines and Soybean mosaic virus incidence in different pest management systems. Plant Dis. 89: 926-934.

[CDMS] Crop Data Management Systems. 2007. Warrior insecticide general use label. (http://www.cdms.net/ manuf $/ 1$ prod.asp?pd $=5603 \& \mathrm{l}_{\mathrm{c}}=0$ )
Clark, A. J., and K. L. Perry. 2002. Transmissibility of field isolates of soybean viruses by Aphis glycines. Plant Dis. 86: $1219-1222$.

Costamagna, A. C., and D. A. Landis. 2006. Predators exert top-down control of soybean aphid across a gradient of agricultural management systems. Ecol. Appl. 16: 16191628.

Davis, J. A., E. B. Radcliffe, and D. W. Ragsdale. 2005. Soybean aphid, Aphis glycines Matsumura, a new vector of Potato virus Y in potato. Am. J. Potato Res. 82: 197-201.

Fernandez-Cornejo, J., and S. Jans. 1999. Pest management in U.S. Agriculture. Resource Economics Division, U.S. Department of Agriculture Economic Research Service, Agriculture Handbook No. 717.

Fox, T. B., D. A. Landis, F. F. Cardoso, and C. D. Difonzo. 2004. Predators suppress Aphis glycines Matsumura population growth in soybean. Environ. Entomol. 33: 608618.

Fox, T. B., D. A. Landis, F. F. Cardoso, and C. D. Difonzo. 2005. Impact of predation on establishment of the soybean aphid, Aphis glycines in soybean, Glycine max. Biol. Control 50: 545-563.

Hodgson, E. W., E. C. Burkness, W. D. Hutchison, and D. W. Ragsdale. 2004. Enumerative and binomial sequential sampling, plans for soybean aphid (Homoptera: Aphididae) in soybean. J. Econ. Entomol. 97: 2127-2136.

Johnson, K. D. 2006. Management of the soybean aphid, Aphis glycines Matsumura (Hemiptera: Aphididae), in Iowa. M.S. thesis, Iowa State University, Ames, IA.

Krell, R. K. 2002. Bean pod mottle virus ecology and management in Iowa. Ph.D. dissertation, Iowa State University, Ames, IA

Krell, R. K., L. P. Pedigo, J. H. Hill, and M. E. Rice. 2003a. Potential primary inoculum sources of bean pod mottle virus in Iowa. Plant Dis. 87: 1416-1422.

Krell, R. K., T. A. Wilson, L. P. Pedigo, and M. E. Rice. 2003b. Characterization of bean leaf beetle (Coleoptera: Chrysomelidae) flight capacity. J. Kans. Entomol. Soc. 76: $406-416$.

Krell, R. K., L. P. Pedigo, J. H. Hill, and M. E. Rice. 2004. Bean leaf beetle (Coleoptera: Chrysomelidae) management for reduction of bean pod mottle virus. J. Econ. Entomol. 97: 192-202.

Krell, R. K., L. P. Pedigo, M. E. Rice, M. E. Westgate, and J. H. Hill. 2005. Using planting date to manage bean pod mottle virus in soybean. Crop Prot. 24: 909-914.

Lam, W.K.F., and L. P. Pedigo. 2000. Cold tolerance of overwintering bean leaf beetles (Coleoptera: Chrysomelidae). Environ. Entomol. 29: 157-163.

Lam, W.K.F., and L. P. Pedigo. 2001. Effect of trichome density on soybean pod feeding by adult bean leaf beetles (Coleoptera: Chrysomelidae). J. Econ. Entomol. 94: $1459-1463$.

Lam, W.K.F., L. P. Pedigo, and P. N. Hinz. 2001. Population dynamics of bean leaf beetles (Coleoptera: Chrysomelidae) in central Iowa. Environ. Entomol. 30: 562-567.

McCornack, B. P., and D. W. Ragsdale. 2006. Efficacy of thiamethoxam to suppress soybean aphid populations in Minnesota soybean. Crop Management. (www. plantmanagmentnetwork.org/sub/cm/research/2006/ $\operatorname{aphid} /$ ).

McCornack, B. P., D. W. Ragsdale, and R. C. Venette. 2004. Demography of soybean aphid (Homoptera: Aphididae) at summer temperatures. J. Econ. Entomol. 97: 854-861.

Myers, S. W., D. B. Hogg, and J. L. Wedberg. 2005a. Determining the optimal timing of foliar insecticide applications for control of soybean aphid (Hemiptera: Aphididae) on soybean. J. Econ. Entomol. 98: 2006-2012. 
Myers, S. W., C. Gratton, R. P. Wolkowski, D. B. Hogg, and J. L. Wedberg. 2005b. Effect of soil potassium availability on soybean aphid (Hemiptera: Aphididae) population dynamics and soybean yield. J. Econ. Entomol. 98: 113120.

Pedigo, L. P., and M. E. Rice. 2006. Entomology and Pest Management. Pearson Prentice Hall, Columbus, $\mathrm{OH}$.

Pedigo, L. P., and M. R. Zeiss. 1996. Effect of soybean planting date on bean leaf beetle (Coleoptera: Chrysomelidae) abundance and pod injury. J. Econ. Entomol. 89: 183-188.

Ragsdale, D. W., D. J. Voegtlin, and R. J. O’Neil. 2004. Soybean aphid biology in North America. Ann. Entomol. Soc. Am. 97: 204-208.

Ragsdale, D. W., B. P. McCornack, R. C. Venette, D. A. Potter, E. W. MacRae, E. W. Hodgson, M. E. O’Neal, K. D. Johnson, R. J. O'Neil, C. D. DiFonzo, et al. 2007. Economic threshold for soybean aphid (Homoptera: Aphididae). J. Econ. Entomol. 100: 1257-1267.

Rice, M. E., M. E. O’Neal, and P. Pedersen. 2005. Soybean aphids in Iowa-2005. IA, SP-247, University Extension, Iowa State University, Ames, IA.

Rutledge, C. E., and R. J. O’Neil. 2005. Orius insidiosus (Say) as a predator of the soybean aphid, Aphis glycines Matsumura. Biocontrol 33: 56-64.

SAS Institute. 2004. SAS/STAT user's guide, version 6.12. SAS Institute, Cary, NC.
Schmidt, N. P. 2006. Management and ecology of aphidophagous natural enemies in Iowa soybeans. M.S. thesis. Iowa State University, Ames, IA.

Schmidt, N. P., M. E. O’Neal, and J. W. Singer. 2007. Alfalfa living mulch advances biological control of soybean aphid. Environ. Entomol. 36: 416-424.

Smelser, R. B., and L. P. Pedigo. 1991. Phenology of Cerotoma trifurcata on soybean and alfalfa in central Iowa. Environ. Entomol. 20: 514-519.

Smelser, R. B., and L. P. Pedigo. 1992. Bean leaf beetle (Coleoptera: Chrysomelidae) herbivory on leaf, stem, and pod components of soybean. J. Econ. Entomol. 85: 2408-2412.

Stern, V. M., R. F. Smith, R. V. Bosh, and K. S. Hagen. 1959. The integrated control concept. Hilgardia 29: 81-101.

Venette, R. C., and Ragsdale, D. W. 2004. Assessing the invasion by soybean aphid (Homoptera: Aphididae): where will it end? Ann. Entomol. Soc. Am. 97: 219-226.

Wang, R. Y., and S. A. Ghabrial. 2002. Effect of aphid behavior on efficiency of transmission of soybean mosaic virus by the soybean aphid, Aphis glycines. Plant Dis. 86: 1260-1264.

Zeiss, M. R., K. J. Koehler, and L. P. Pedigo. 1996. Degreeday requirements for development of the bean leaf beetle (Coleoptera: Chrysomelidae) under two rearing regimes. J. Econ. Entomol. 89: 111-118.

Received 21 May 2007; accepted 11 February 2008. 